\title{
Hype or Hope: Digital Technologies in Auditing Process
}

\author{
Mohamad Hesham Adnan Allbabidi*
}

\begin{abstract}
Manuscript type: Research paper

Research aims: This study aims to examine how technological, organisational and environmental (TOE) factors affect digital technologies' utilisation and its impact on auditors' performance.

Design/Methodology/Approach: A survey was conducted on 4 large and non-large companies in Jordan, and data were retrieved from 168 external auditors. The partial least squares (PLS-3) structural equations modeling was used to analyse data and to test the proposed model.
\end{abstract}

Research findings: Results show that the TOE factors have a significant and positive effect on digital technologies utilisation. It also appears to enhance auditors' performance.

Theoretical contribution/Originality: This study fills a gap in the literature of accounting by empirically assessing how digital technologies utilisation impacts the performance of auditors in Jordan. It also expands on previous literature by determining how the TOE factors affect such technology usage in the auditing process. This study also has a methodological contribution in the form of measuring the client's complexity of IT system from a different perspective, which is from the external auditor's perspective.

Practitioner/Policy implications: This study is expected to help regulators and audit companies to update their policies and regulations so that auditors are trained in using advanced technologies, and in protecting the security of accounting information. In this regard, efficient

\footnotetext{
* Mohamad Hesham Adnan Allbabidi is an Assistant Professor at the Department of Accounting, Al-Salt College for Human Sciences, Al-Balqa Applied University, 19117, Salt, Jordan. Email: mohamadlbabidi@yahoo.com
} 
auditors will be able to protect investors, thereby creating an attractive environment for investment which can boost economic growth.

Research limitation/Implications: This study is based on the Jordanian context. There was no comparison made with developing or developed countries, hence no distinctions can be detected. Future studies should focus on looking at other countries so as to provide new insights into the auditing profession, and specifically, auditors' performance. Finally, this study is a practical guide for external and internal auditors who have not considered digital technologies, in the context of Jordan. Future studies may thus consider internal auditors and their relationship with external auditors in digital technologies utilisation.

Keywords: Technological, Organisational and Environmental Factors, Auditors' Performance, Digital Technologies JEL Classification: M42

\section{Introduction}

To date, the use of digital technologies has become increasingly important as it paves the way for investors to make effective and efficient business decisions, (Handoko et al., 2018). Companies invest in digital technologies so as to improve their operational performance and their financial reporting quality (Wicaksono \& Lusianah, 2016). Further to this, Bierstaker et al. (2014) also mentioned that digital technology is a very useful tool for external auditors who can use it to perform their audit duties more efficiently, especially in a big data environment. In a more recent study, Cristea (2020) and Lee and Tajudeen (2020) observed that artificial intelligence to automate the traditional data analysis process, which includes collecting and preparing audit data, copying and transposing information between the database/software (e.g., SAP) and tools (e.g., Microsoft Excel), organising the information based on several selection criteria, integrating manual notes, and running basic tests. All of these processes have enhanced the auditing process very much, and this implies that technology advancement can facilitate auditors' performance. It helps to make the auditors' tasks more effective and efficient, for instance, in ensuring the internal control of the auditees, in accessing documents and records, and in producing information, when compared to their manual auditing approach. Although many businesses have moved towards using sophisticated IT-based environments, auditor readiness and progress in this regard has been slow (Bierstaker et al., 
2014). At the same time, IT audits in developing countries is still at the minimum level (Mansour, 2016; Ismail \& Abidin, 2009). This implies that some companies may be experiencing some disadvantages. Several researchers such as Al-Ansi (2015) and Gibran (2010), argued that external auditors should bear part of the responsibilities for companies' bankruptcy and their business failures. This is because stakeholders expect auditors to provide credible and quality information. One of the ways to meet these increasing demands is by using audit technologies which can assist auditors in detecting false penetrations and frauds more efficiently (Bierstaker et al., 2014; International Federation of Accountants, 2019), thereby improving auditors' performance (International Accounting Education Standards Board, 2014).

In the context of Jordan, computerised accounting information systems used by companies and banks had helped to expose instances of electronic penetration and hacking (Mansour, 2016). Cases of credit cards issued by Jordanian banks being hacked had also occurred, involving at least 500 Visa credit cards which had led to a loss of 5 million JD (Central Bank of Jordan, 2018). This crisis raised some ambiguities about the performance of Jordanian external auditors. There is thus, an urgent need to develop a deliberate study which can address this issue. Endorsements have been made by Marie (2015), and Al-Hanini (2009), who had proposed that external auditors need to keep up to date with the changes that have occurred in Jordanian IT, which is currently being utilised as a tool in the field of accounting. The scholars maintained that external auditors need to include IT into their system so as to improve their performance.

The effects of technological factors (Handoko et al., 2018; Al-Ansi, 2015), and organisational factors (Bierstaker et al., 2014; Wicaksono \& Lusianah, 2016; Curtis \& Payne, 2014) on digital technologies' utilisation have been examined previously. Although these studies provided some insights into the adoption and usage of technology in auditing, there were some limitations in terms of environmental factors. Thus several scholars (Marie, 2015; Mansour, 2016; Lim-u-sanno \& Ussahawanitchakit, 2009) highlighted the need for studies to integrate the environmental factors into their investigations. It was argued that the influence of professional bodies, as an environmental factor, cannot be neglected within the auditing context (Mansour, 2016; Lim-u-sanno \& Ussahawanitchakit, 2009).

Statutory guidelines derived from auditors' association of professional bodies have stated that digital technology is important. However, 
even though these professional bodies may serve as the legal body to raise auditing standards, its importance as an environmental factor has not been much examined. Further to this, past studies have also overlooked the impact of digital technologies on auditors' performance. Given the limitations of previous studies, there is thus a need to conduct a study, particularly within the context of Jordan as a developing country, to examine how these two factors are interrelated. To date, the audit profession in Jordan is also facing many difficulties which could be enhanced by more research focusing on information technology auditing (Mansour, 2016; Al-Hanini, 2009). Past studies have mainly focused on western countries which are typically characterised by their individualistic culture, hence the current study aims to examine the context of an Arabic community that possesses a collectivistic culture where its social life is more dominating than its private life (Marie, 2015). In this regard, Jordan serves as an interesting setting.

This study addresses the gap identified in existing accounting literature by empirically assessing the impact of TOE factors on digital technologies' utilisation and its impact on auditors' performance, in the context of Jordan. This study also makes a methodological contribution by measuring the companies' complexity of IT system, from the perspective of the external auditors. The findings of this study are expected to enable regulators and audit firms to update their policies and regulations so that auditors can be mandatorily trained in the use of advanced technologies which can then enhance their performance. The auditors' efficiency would then be able to offer protection to investors, thereby creating an attractive environment for boosting the overall economic growth.

This paper is organised in the following manner: Section 2 discusses the literature review and hypotheses development. Section 3 explains the methodology. Section 4 reports on the findings, Section 5 focusses on the discussions and Section 6 concentrates on the implications and limitations of the study.

\section{Literature Review}

\subsection{Auditor Performance}

Auditor performance is defined as the total expected values offered, and the behaviours conducted by auditors. Recent financial crises have highlighted old and new questions concerning auditors' performance, 
which point to the credibility of financial statements prepared by auditors. Traditionalists contend that external audits contribute to the credibility of financial statements because auditors are trained to be insightful; they also possess the knowledge that can be used to curtail poor management as well as to facilitate the production of accurate information (Handoko et al., 2018; Sikka, 2009). In relation to this, Curtis and Payne (2014) emphasised that improving audit performance is of particular importance in today's audit environment that is characterised by increased responsibilities and workloads, especially fraud detections. This task is especially mandated by SAS No. 99, which states that suboptimal performance, particularly in situations where task complexity exceeds individual skills and experience, can be improved.

Technological advancement, to some extent, has disrupted the audit profession as auditing firms strive to keep abreast with the technologies. The adoption of new and smart technologies can lead to improvements in many aspects of the professions' quality, hence it is vital to implement the technology. Since mid-2000, there has been a marked increase in the introduction of technologies. This has impacted auditors' role and profession (La Torre et al., 2018; Kozlowski, 2018). Techniques such as continuous auditing and computer assisted audit techniques (CAATs) require that auditors adopt advanced electronic environments (Lamboglia \& D'Onza, 2014; Curtis \& Payne, 2014; Braun \& Davis, 2003). Despite the relevant effects and widespread diffusion of technology in auditing, these issues seem to be under-researched. While literature on digital technologies is vast, ranging from engineering to a wide set of applications in many areas of research, research examining their applications in the audit profession is far in between (Issa et al., 2016).

\subsection{Theory of Technology-Organisation-Environment (TOE)}

In examining the technological, organisation, and environment factors that may influence the performance of the Jordanian external auditors, this study employs the theory of technology-organisation-environment (TOE) as a framework. Developed by Tornatzky and Fleisher (1990) for the purpose of analysing information technology adoption by companies, the TOE is a technology acceptance model. Using this

framework, Tornatzky and Fleisher (1990) was able to identify the factors that influenced technology adoption among companies. The first of these, the technological context describes both the external and internal technologies relevant to a company. This includes current firm 
practices (Lin \& Lin, 2008) as well as the available external technologies (Pan \& Jang, 2008). The second, organisational context, refers to the organisation's scope, managerial structure and size (Oliveira \& Martins, 2008), and finally, the environmental context refers to how the organisation conducts its businesses which comprise the nature of the industry, government dealings and its competitors (Tornatzky \& Fleischer, 1990).

The TOE framework serves as a useful analytical structure for examining the adoption and assimilation of different information technology innovations. The TOE framework has a consistent empirical support, a solid theoretical basis, and various potential applications in information system innovations (Awa et al., 2015). However, some specific factors may vary across different studies. Based on the TOE theory, this study incorporates three factors, namely the technological factors, organisational factors and environmental factors, which are deemed to influence digital technologies' utilisation among companies.

\subsubsection{Technological Factors}

The technological factors are evaluated based on three dimensions - IT knowledge, IT cognitive style and IT self-efficacy. IT knowledge refers to the individual's ability to describe the conceptual or theoretical aspect of the technology (International Federation of Accountants, 2019). It is deduced that auditors' computer knowledge would enhance their positive perceptions on digital technologies (Mansour, 2016). It appears that users who have IT knowledge tend to develop positive experiences when using the system. Thus, they are more likely to utilise the system in the future. They also tend to have the confidence that using digital technologies could facilitate their performance in their auditing tasks, thereby leading to higher utilisation (Wicaksono \& Lusianah, 2016; AlAnsi, 2015). Based on these arguments, the following hypothesis was formulated:

$\mathrm{H}_{1 \mathrm{a}}$ : IT knowledge has a positive effect on digital technologies' utilisation.

Results from prior studies have shown that IT cognitive styles can affect the individual's decision-making and behaviour, significantly (Chakraborty et al., 2008; Handoko et al., 2018; Marie, 2015). Cognitive style is defined by Messick (1976, p. 4) as "stable attitudes, preferences or habitual strategies that determine individuals' modes of perceiving, 
remembering, thinking and problem solving". It has been noted that cognitive style can significantly and positively impact on the individual's perception of IT importance (Chakraborty et al., 2008). Individuals who perceive that new technologies can be useful, and are easy to use, tend to increase IT utilisation, and past studies seemed to show consistency. For instance, Al-Ansi (2015) found that cognitive style positively influenced the individuals' perceived IT importance and utilisation. Based on the above, the following hypothesis was formulated:

$\mathrm{H}_{1 \mathrm{~b}}$ : IT cognitive style has a positive effect on digital technologies' utilisation.

Self-efficacy refers to the person's belief in his/her own capability and ability to organise and execute a course of action so as to produce a desired outcome (Bandura, 1997). Within the context of technology, individuals with high self-efficacy tend to be more confident in using the tools; they enjoy the usage, and they experience less anxiety about using them (Chakraborty et al., 2008). This argument was also endorsed by Mansour (2016) who mentioned that self-efficacy can influence performance expectations. Likewise, Wicaksono and Lusianah, (2016) deduced that self-efficacy has a significant impact on IT utilisation. Based on the above arguments, the following hypothesis was thus formulated:

$\mathrm{H}_{1 \mathrm{c}}$ : IT self-efficacy has a positive effect on digital technologies' utilisation.

\subsubsection{Organisational Factors}

In this study, the organisational factors were evaluated based on three dimensions, which include management support, IT training and IT facilitating resources. Management support is defined as the perceived level of general support offered by senior executives and decision makers (Igbaria et al., 1997). The active involvement of management increases the strategic importance of the technology usage (Ahmi \& Kent, 2013). Without the support of the management, technology development could not be manifested across organisations because it requires substantial financial resources. Within the context of auditing, Curtis and Payne (2014) found that management support leads to increased IT usage. Based on this, the following hypothesis was thus proposed:

$\mathrm{H}_{2 \mathrm{a}}$ : IT management support has a positive effect on digital technologies' utilisation. 
With the development of information technology, devices are being introduced more rapidly into the market. This also leads to organisations investing in financial resources so as to acquire the latest available technology. Despite this, technologies are being under-utilised mainly because of the employees' incapability to use them. This phenomenon suggests the importance of IT training so as to optimise technology usage (Yi \& Davis, 2001). IT training helps employees to update their skills, and to reduce their anxiety towards technology adoption, thereby leading to high utilisation. In the auditing context, studies done by Al-Ansi (2015), Mansour (2016), and Handoko et al. (2018) found a positive relationship between IT training and IT utilisation. Given these arguments, the following hypothesis was thus formulated:

$\mathrm{H}_{2 \mathrm{~b}}$ : IT training has a positive effect on digital technologies' utilisation.

Curtis and Payne (2014), and Ahmi and Kent (2013) found that IT usage can be hindered by the limited access to hardware and software facilities. This means that the individual's perception of control over the use of technology is influenced by the available IT facilitating resources. Venkatesh et al. (2003, p. 453) defined IT facilitating resources as "the degree to which an individual believes that an organisational and technical infrastructure exists to support use of the system". In the auditing context, auditors are more likely to use technologies like the CAAT, if they believe that the organisation provides them with the necessary IT support (Bierstaker et al., 2014). Based on these arguments, it is thus expected that IT facilitating resources would positively affect digital technologies utilisation; hence the following hypothesis was formulated:

$\mathrm{H}_{2 \mathrm{c}}$ : IT facilitating resources have a positive effect on digital technologies' utilisation.

\subsubsection{Environmental Factors}

In this study, the environmental factors were evaluated based on complexity of clients' IT system, their competitive pressure, and the regulations imposed by professional bodies. Control risk may influence computer-related audit procedures when examining clients with complex IT system (American Institute of Certified Public Accountants, 2012). For example, SAS No. 94 cautions auditors that determining control risks 
at maximum level, and relying only on testing as a procedure, may not be sufficiently effective for clients with complex IT systems. Moreover, professional standards suggest that auditors should consider control risks during planning, when examining clients with complex IT systems (American Institute of Certified Public Accountants, 2011). Al-Ansi et al. (2013) also agreed with Al-Kharbi (2010) that if external auditors were not updated in terms of the IT usage, they would be unable to cope with other challenges being imposed by the technology-driven business environment. In support of that, Marie (2015) asserted that those interested in the audit profession are well aware of the gap existing between the actual practice of auditors, and the improvements noted in the IT-related auditing profession. Based on this, it is thus expected that the complexity of client's system has a positive influence on their IT utilisation. Hence, the following hypothesis was proposed:

$\mathrm{H}_{3 \mathrm{a}}$ : Perceived complexity of clients' IT system has a positive effect on digital technologies' utilisation.

Recent audit-market pressures have led to radical changes in the audit methodologies of some audit companies (Mansour, 2016). To increase both the audit effectiveness and its value to clients, audit firms are persuaded to adopt new technologies (Berberich, 2005). More than a few regulators and researchers have raised concerns about the ability of small audit companies in competing with larger companies in the IT environment (Handoko et al., 2018). This shows that competition drives the auditing firms to consider technology investment so as to maintain their competitiveness. Companies' adoption of advanced technologies may enable these auditing firms to leverage on newer and more efficient ways of auditing, hence the ability to outperform their rivals. The utilisation of the state-of-the-art technologies would help such auditing firms to position themselves as a leading-edge auditing firm. Based on this, it is expected that competitive pressure has a positive influence on digital technologies' utilisation. Thus, the following hypothesis was formulated:

$\mathrm{H}_{3 \mathrm{~b}}$ : Competitive pressure has a positive effect on digital technologies' utilisation.

Professional bodies are sources for helping members to remain well-informed, and to sustain their relevance. They also ensure that members conform to international professional standards and practices (American Institute of Certified Public Accountants, 2012). 
Undoubtedly, regulations and laws related to IT increase the awareness of IT importance among auditors (International Accounting Education Standards Board, 2014; International Federation of Accountants, 2019). Prior literature (Curtis \& Payne, 2014; Al-Ansi, 2015; Wicaksono \& Lusianah, 2016) has highlighted the relationship between professional associations and technology adoption. It is deemed that auditors' acceptance of IT would increase if they are encouraged by their professional associations to adopt these audit technologies. Based on this, it is therefore deduced that regulations done by professional bodies have a positive influence on auditors' digital technologies utilisation. Based on the above, the following hypothesis was formulated:

$\mathrm{H}_{3 c}$ : Regulations of professional bodies have a positive effect on digital technologies' utilisation.

\subsubsection{Digital Technologies' Utilisation and Auditors' Performance}

The effective use of IT generates innovations; it can also help firms to redesign their business processes, which, together with positive dynamics, can subsequently lead to enhanced performance (Handoko et al., 2018). IT utilisation can influence business performance in several ways such as: 1) by altering richness perceptions of IT importance; and 2) by affecting performance, that is, to improve the efficiency and effectiveness of businesses (Wicaksono \& Lusianah, 2016). Auditing standards proposed by associations have also stated that IT utilisation may improve audit performance (Bierstaker et al., 2014). Interestingly, auditors had previously indicated that IT utilisation is important for several applications (audit planning, risk assessment, internal control evaluation, client acceptance, client relationship management, and fraud review) (Mansour, 2016). IT utilisation is equally important because audit technologies make it possible for auditors to improve their performance (Al-Ansi, 2015). Therefore, it is believed that IT utilisation would have a positive influence on auditors' performance. Based on this, the following hypothesis was formulated:

$\mathrm{H}_{4}$ : Digital technologies' utilisation has a significant and positive effect on auditors' performance.

Based on the literature review, and the formulated hypotheses, a research framework was thus developed for this study. Figure 1 illustrates. 


\section{Technological Factors \\ IT knowledge \\ IT cognitive style \\ IT self-efficacy}

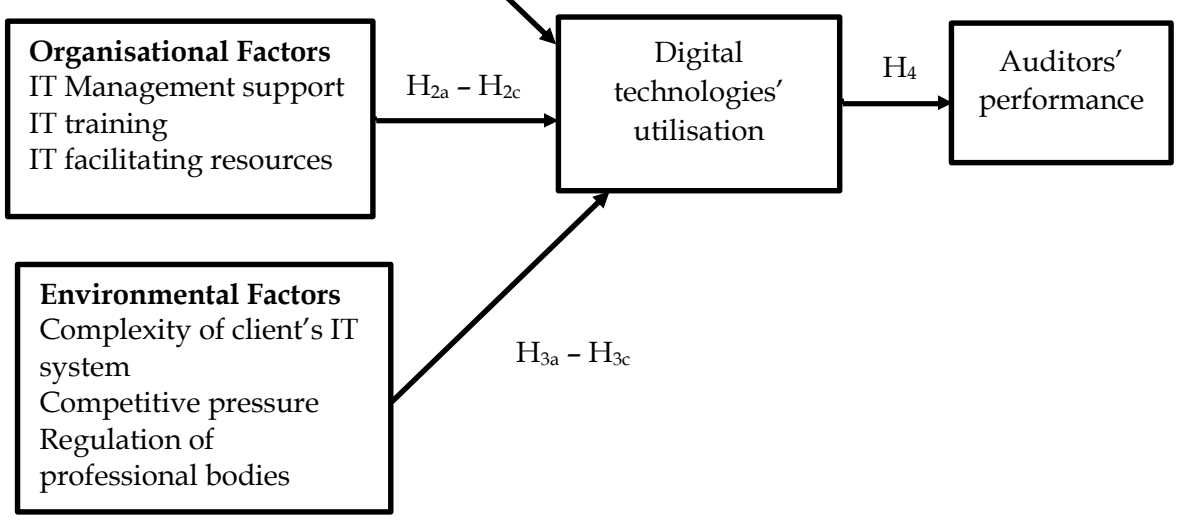

Figure 1: Research Framework

\section{Methodology}

This study employs a quantitative approach based on a survey questionnaire which was used to test the research hypotheses. The research population for this study comprised Jordanian auditors of various ranks, including audit partners, audit senior managers, audit managers, senior auditors, junior auditors, audit trainees, or other equivalent positions. The questionnaire was pilot tested with 40 respondents from 4 large and non-large companies. Based on the 32 responses received, the inconsistencies of wording, and unclear or ambiguous items listed in the questionnaire were refined. According to the Jordanian Association of Certified Public Accountants (2019), the total population of Jordanian external auditors are, of date, 360. Using the rand () function noted in MS Excel, random numbers were then generated. These were first sorted, and then selected, from the 186 external auditors who represented 4 large and non-large companies. Prior to the questionnaire distribution, formal approval was acquired from the auditors who participated in the survey and their top management. This is pertinent because the Jordanian government has a stringent regulation that prohibits Jordanian auditors from participating in any study without the consent of their companies' 
top management. Once the permission was granted, the questionnaires were personally distributed to external auditors who were randomly selected from different areas in Jordan. Of the 186 questionnaires administered, a total of 168 were retrieved, resulting in a 90.32 per cent response rate, hereby considered high. This was possible because the questionnaires were personally distributed, which was the most preferred approach, instead of online distribution or by the telephone. In this study, each construct or variable was measured through the use of multi-items adapted from previous studies. These were measured based on the 5-point Likert-scale. Appendix 1 further illustrates.

\section{Analysis and Findings}

The partial least squares (PLS-3) structural equation modeling was employed to test the conceptual model and the developed hypotheses. Majority of the respondents were males (69.6 per cent), aged between 20 to 29 years old (54.8 per cent). More than half (59.5 per cent) of the respondents possessed a bachelor's degree and had been working for more than 10 years (27.4 per cent). A total of 91.7 per cent of the respondents had professional qualifications, with majority of them possessing the JACPA, and most being Junior Auditors. Table 1 summarises the demographic profiles.

\subsection{Measurement Model Analysis}

The measurement model analysis was performed so as to examine the model's reliability and validity. This was assessed through convergent validity and discriminant validity tests. As shown in Table 2, the factor loadings for all items were between 0.548 and 0.956 , which were above the threshold value of 0.5 (Hair et al., 2017). Both the composite reliability (CR), and average variance extracted (AVE) scales were above the accepted values of 0.5 . These figures implied that the items satisfied the convergent validity test.

Besides convergent validity, the current study also uses discriminant validity to strengthen the findings. As per past studies, the discriminant validity is only deemed to exist if the value of the average variance extracted for a particular construct is higher than its correlation with other constructs (Hair et al., 2017). As noted in Table 3, all constructs had AVE values which were substantially higher than their correlation with other constructs, indicating that there was discriminant validity. 
Table 1: Demographic Summary of Survey Respondents

\begin{tabular}{|c|c|c|c|}
\hline $\begin{array}{l}\text { Demographic } \\
\text { Variables }\end{array}$ & Category & Frequency & $\begin{array}{l}\text { Percentage } \\
\quad(\%)\end{array}$ \\
\hline \multirow[t]{2}{*}{ Gender } & Male & 117 & 69.6 \\
\hline & Female & 51 & 30.4 \\
\hline \multirow[t]{5}{*}{ Age } & $20-29$ years & 92 & 54.8 \\
\hline & $30-39$ years & 28 & 16.7 \\
\hline & $40-49$ years & 20 & 11.9 \\
\hline & $50-59$ years & 22 & 13.1 \\
\hline & 60 years and above & 6 & 3.6 \\
\hline \multirow[t]{4}{*}{ Educational Level } & Diploma & 13 & 7.7 \\
\hline & Bachelor & 100 & 59.5 \\
\hline & Master & 42 & 25.0 \\
\hline & Doctorate & 13 & 7.7 \\
\hline \multirow[t]{5}{*}{ Experience } & Never & 14 & 8.3 \\
\hline & Less than 1 year & 23 & 13.7 \\
\hline & $2-5$ years & 44 & 26.2 \\
\hline & $6-10$ years & 41 & 24.4 \\
\hline & Above 10 years & 46 & 27.4 \\
\hline \multirow[t]{2}{*}{ Professional qualification } & Yes & 154 & 91.7 \\
\hline & No & 14 & 8.3 \\
\hline \multirow{5}{*}{$\begin{array}{l}\text { Type of professional } \\
\text { qualification }\end{array}$} & CPA & 51 & 30.4 \\
\hline & ACCA & 11 & 6.5 \\
\hline & CMA & 12 & 7.1 \\
\hline & JACPA & 80 & 47.6 \\
\hline & No qualification & 14 & 8.3 \\
\hline \multirow[t]{6}{*}{ Current position } & Audit Partner & 31 & 18.5 \\
\hline & Audit Senior Manager & 24 & 14.3 \\
\hline & Audit Manager & 22 & 13.1 \\
\hline & Senior Auditor & 33 & 19.6 \\
\hline & Junior Auditor & 44 & 26.2 \\
\hline & Audit Trainee & 14 & 8.3 \\
\hline
\end{tabular}


Table 2: Convergent Validity of Measurement Model

\begin{tabular}{|c|c|c|c|c|c|}
\hline Constructs & Items & $\begin{array}{c}\text { Factor } \\
\text { Loadings }\end{array}$ & $\begin{array}{c}\text { Average } \\
\text { Variance Ex- } \\
\text { tracted (AVE) }\end{array}$ & $\begin{array}{c}\text { Cronbach's } \\
\text { Alpha }\end{array}$ & $\begin{array}{c}\text { Composite } \\
\text { Reliability } \\
\text { (CR) }\end{array}$ \\
\hline IT Knowledge & $\begin{array}{l}\text { ITK1 } \\
\text { ITK2 } \\
\text { ITK3 } \\
\text { ITK4 } \\
\text { ITK5 }\end{array}$ & $\begin{array}{l}0.816 \\
0.763 \\
0.811 \\
0.625 \\
0.754\end{array}$ & 0.573 & 0.839 & 0.869 \\
\hline $\begin{array}{l}\text { IT Cognitive } \\
\text { Style }\end{array}$ & $\begin{array}{l}\text { ITCS1 } \\
\text { ITCS2 } \\
\text { ITCS3 } \\
\text { ITCS4 } \\
\text { ITCS5 }\end{array}$ & $\begin{array}{l}0.759 \\
0.744 \\
0.784 \\
0.797 \\
0.787\end{array}$ & 0.545 & 0.719 & 0.825 \\
\hline IT Self-Efficacy & $\begin{array}{l}\text { ITSE1 } \\
\text { ITSE2 } \\
\text { ITSE3 } \\
\text { ITSE4 }\end{array}$ & $\begin{array}{l}0.589 \\
0.755 \\
0.863 \\
0.720\end{array}$ & & & \\
\hline $\begin{array}{l}\text { IT Manage- } \\
\text { ment Support }\end{array}$ & $\begin{array}{l}\text { ITMS1 } \\
\text { ITMS2 } \\
\text { ITMS3 } \\
\text { ITMS4 }\end{array}$ & $\begin{array}{l}0.838 \\
0.928 \\
0.842 \\
0.800\end{array}$ & 0.728 & 0.875 & 0.914 \\
\hline IT Training & $\begin{array}{l}\text { ITT1 } \\
\text { ITT2 } \\
\text { ITT3 } \\
\text { ITT4 }\end{array}$ & $\begin{array}{l}0.887 \\
0.887 \\
0.707 \\
0.772\end{array}$ & 0.667 & 0.834 & 0.888 \\
\hline $\begin{array}{l}\text { IT Facilitating } \\
\text { Resources }\end{array}$ & $\begin{array}{l}\text { ITFR1 } \\
\text { ITFR2 } \\
\text { ITFR3 } \\
\text { ITFR4 } \\
\text { ITFR5 }\end{array}$ & $\begin{array}{l}0.889 \\
0.870 \\
0.851 \\
0.756 \\
0.773\end{array}$ & 0.688 & 0.886 & 0.917 \\
\hline $\begin{array}{l}\text { Complexity of } \\
\text { Clients' IT } \\
\text { System }\end{array}$ & $\begin{array}{l}\text { CCS1 } \\
\text { CCS2 } \\
\text { CCS3 }\end{array}$ & $\begin{array}{l}0.861 \\
0.956 \\
0.934\end{array}$ & 0.843 & 0.917 & 0.941 \\
\hline $\begin{array}{l}\text { Competitive } \\
\text { Pressure }\end{array}$ & $\begin{array}{l}\text { CP1 } \\
\text { CP2 } \\
\text { CP3 } \\
\text { CP4 }\end{array}$ & $\begin{array}{l}0.873 \\
0.612 \\
0.776 \\
0.548\end{array}$ & 0.510 & 0.703 & 0.801 \\
\hline $\begin{array}{l}\text { Regulations of } \\
\text { Professional }\end{array}$ & $\begin{array}{l}\text { RPBJ1 } \\
\text { RPBJ2 }\end{array}$ & $\begin{array}{l}0.907 \\
0.793\end{array}$ & 0.572 & 0.842 & 0.868 \\
\hline
\end{tabular}


Table 2: Continued

\begin{tabular}{llcccc}
\hline Constructs & Items & $\begin{array}{c}\text { Factor } \\
\text { Loadings }\end{array}$ & $\begin{array}{c}\text { Average } \\
\text { Variance Ex- } \\
\text { tracted (AVE) }\end{array}$ & $\begin{array}{c}\text { Cronbach's } \\
\text { Alpha }\end{array}$ & $\begin{array}{c}\text { Composite } \\
\text { Reliability } \\
\text { (CR) }\end{array}$ \\
\hline Bodies in & RPBJ3 & 0.719 & & & \\
Jordan & RPBJ4 & 0.687 & & & \\
& RPBJ6 & 0.647 & & \multirow{2}{*}{0.985} & \\
\hline Auditors' & AP1 & 0.805 & 0.637 & & \\
Performance & AP2 & 0.848 & & & \\
& AP3 & 0.735 & & & \\
& AP4 & 0.725 & & & \\
& AP5 & 0.867 & & & \\
& AP6 & 0.796 & & & \\
\hline Digital & DTU1 & 0.889 & 0.975 & \\
Technologies' & DTU2 & 0.715 & & & \\
Utilisation & DTU3 & 0.805 & & & \\
& DTU4 & 0.773 & & & \\
& DTU5 & 0.857 & & & \\
\hline
\end{tabular}

Table 3: Discriminant Validity Analysis

\begin{tabular}{|c|c|c|c|c|c|c|c|c|c|c|c|}
\hline Constructs & CCS & $\mathrm{CP}$ & ITCS & ITFR & ITK & ITMS & ITSE & ITT & $\mathrm{AP}$ & RPBJ & DTU \\
\hline CCS & 0.918 & & & & & & & & & & \\
\hline $\mathrm{CP}$ & 0.218 & 0.714 & & & & & & & & & \\
\hline ITCS & 0.244 & 0.337 & 0.774 & & & & & & & & \\
\hline ITFR & 0.308 & 0.593 & 0.499 & 0.829 & & & & & & & \\
\hline ITK & 0.126 & 0.327 & 0.323 & 0.490 & 0.757 & & & & & & \\
\hline ITMS & 0.256 & 0.541 & 0.412 & 0.508 & 0.250 & 0.853 & & & & & \\
\hline ITSE & 0.361 & 0.463 & 0.490 & 0.526 & 0.322 & 0.613 & 0.738 & & & & \\
\hline ITT & 0.182 & 0.620 & 0.217 & 0.551 & 0.486 & 0.637 & 0.485 & 0.817 & & & \\
\hline $\mathrm{AP}$ & 0.165 & 0.578 & 0.508 & 0.710 & 0.423 & 0.720 & 0.532 & 0.651 & 0.798 & & \\
\hline RPBJ & 0.371 & 0.007 & 0.204 & 0.057 & 0.316 & 0.108 & 0.108 & 0.039 & 0.292 & 0.756 & \\
\hline DTU & 0.201 & 0.312 & 0.220 & 0.525 & 0.426 & 0.270 & 0.641 & 0.523 & 0.350 & 0.567 & 0.770 \\
\hline
\end{tabular}

Notes: The numbers in bold in the diagonal row are square roots of the AVE, SD = Standard Deviation, $\mathrm{M}=$ Mean, CCS = Complexity of Clients' Systems, CP $=$ Competitive Pressure, ITCS $=$ IT Cognitive Style, ITFR $=$ IT Facilitating Resources, ITK = IT Knowledge, ITMS = IT Management Support, ITSE = IT SelfEfficacy, $\mathrm{ITT}=\mathrm{IT}$ Training, $\mathrm{AP}=$ Auditors' Performance, $\mathrm{RPBJ}=$ Regulations of Professional Bodies in Jordan, DTU = Digital Technology Utilisation. 


\subsection{Structural Model Analysis}

Assuming that the measurement model satisfied the convergent and discriminant validity, a structural model was thus developed and then tested. The $\mathrm{R}$ square value for the auditors' performance and their digital technologies' utilisation were recorded at 0.754 , and 0.683 , respectively. This indicates that a substantially adequate model has been developed. Table 4 presents the hypotheses testing results. The results revealed that IT knowledge $(\beta=0.527, t=3.253, p<0.001)$, IT cognitive style $(\beta=0.321$, $\mathrm{t}=1.368, \mathrm{p}<0.05)$, IT self-efficacy $(\beta=0.374, \mathrm{t}=4.521, \mathrm{p}<0.001)$, IT management support $(\beta=0.111, \mathrm{t}=2.150, \mathrm{p}<0.05)$, IT training $(\beta=0.224, \mathrm{t}=3.298$, $p<0.01)$, IT facilitating resources $(\beta=0.303, t=5.265, p<0.001)$, perceived complexity of clients' IT system $(\beta=0.126, t=2.541, p<0.05)$, competitive pressure $(\beta=0.155, \mathrm{t}=3.187, \mathrm{p}<0.05)$, and regulations of professional bodies $(\beta=0.192, t=5.225, p<0.001)$, all had positive impact on digital technologies' utilisation. These results further supported $\mathrm{H}_{1 \mathrm{a}}, \mathrm{H}_{1 \mathrm{~b}}, \mathrm{H}_{1 c}, \mathrm{H}_{2 a}$ $\mathrm{H}_{2 b}, \mathrm{H}_{2 c}, \mathrm{H}_{3 a}, \mathrm{H}_{3 \mathrm{~b}}$ and $\mathrm{H}_{3 \mathrm{c}}$. This showed the evidence which indicates that digital technologies' utilisation had a significant influence on auditors' performance $(\beta=0.160, t=5.225, p<0.001)$. Hence, $H_{4}$ was supported.

\section{Discussion}

This study aims to investigate the impact of technological, organisational and environmental factors on digital technologies' utilisation. It also attempts to investigate the relationship between digital technologies' utilisation and auditors' performance. Consistent with previous studies (Curtis \& Payne, 2014; Chakraborty et al., 2008; Schwarzer, 2014), this study lends credence to the importance of technological, organisational and environmental factors, as noted through the findings. The move to industrial revolution 4.0 has brought about many emerging software/ applications/hardware to the auditors' working environment (Lois, et al., 2020; Dbouk \& Zaarour, 2017). Such a situation may cause a "change" in the auditing process, and as a result, some aspects of judgments had become digitised. The robotic process automation has replaced the traditional revenue and payroll testing process, hence in the new auditing method, different machine learning techniques are being applied. This helps to create a predictive model which can impact the auditing process. While the emergence of these technologies may be a tool that could improve the auditing process, the changes these technologies imposed on organisations may be perceived differently by 
Hype or Hope: Digital Technologies in Auditing Process

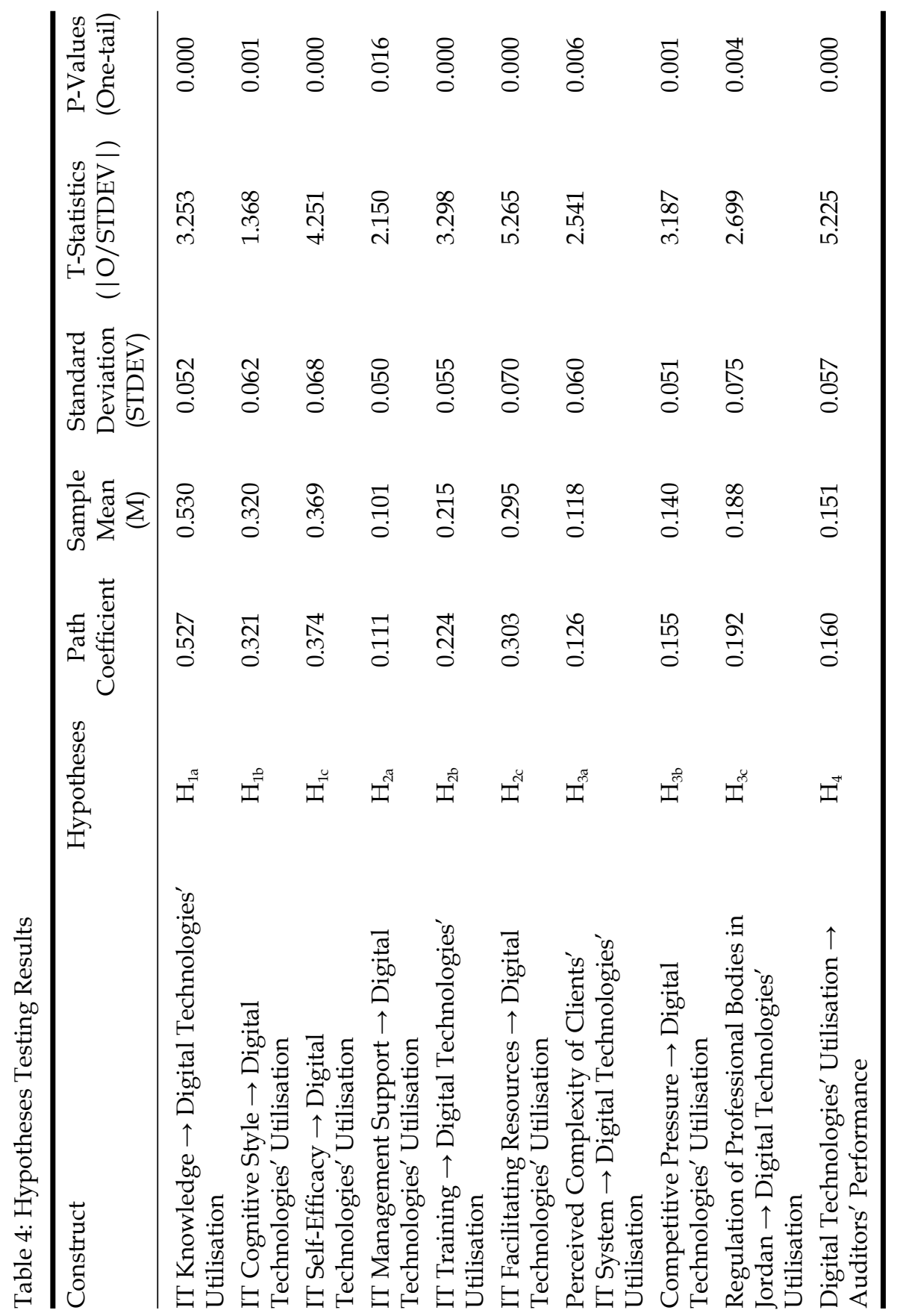


different auditors, depending on their level of self-efficacy and comfort in using the technologies (Wicaksono \& Lusianah, 2016). Consequently, some auditors may hesitate in utilising these digital technologies. They may refrain from adapting to the changes, and from learning new things due to their low confidence, and their lack of technology "savviness". It is probable that their lack of adequate IT skills and knowledge may cause them to perform their job less effectively. In some extent, their lack of skills and knowledge may cause them anxiety, which then lowers their optimisation in digital technologies' utilisation (Mansour, 2016; Handoko et al., 2018). The continuous upgrading of technologies may also unsettle their confidence, thereby leading to the need for them to be retrained several times. A process of this nature may lead to substantial training costs for the organisations. Based on this, it is not surprising, that without the support of the management, digital technologies and their benefits may not materialise.

The rapid advancement of digital technologies and the benefits they bring to the auditing process have enabled many large accounting firms to introduce the use of technology, such as artificial intelligence, in making audit judgments (Serpeninova, et al., 2020). This advancement may pressurise the auditors into changing their conventional auditing process to something more current, so as to stay ahead of current changes. As auditing firms are regulated by professional accounting bodies, there is no doubt that the auditing standards issued by the professional bodies would help to increase their awareness on current and new technologies that would enhance their management of accounting issues (Curtis \& Payne, 2014). As members of the professional bodies, these auditors would be influenced to utilise these digital technologies, as noted by the current study. This outcome may be due to the fact that many of the respondents in the current study were from large enterprises with large accounting transaction volumes, which may be overwhelming and less manageable to be audited manually. In that regard, it explains why these large auditing firms would require a complex accounting information system (Pratoomsuwan, 2017). Thus, there is a need for the auditors concerned to use digital technologies, which are more advanced, in order to perform their auditing tasks more efficiently.

\section{Implications and Conclusion}

In conclusion, this paper presents the extent of digital technologies' utilisation in the auditing context by focussing on the technological, 
organisational and environmental (TOE) framework. Theoretically, it contributes to existing literature by incorporating the environmental factors into the framework; it also measures the complexity of clients' IT system from the perspective of external auditors. This study also expands on previous literature by investigating the impact of digital technologies' utilisation on auditors' performance.

With the emergence of industrial revolution 4.0, audit firms, professional bodies, and regulators are beginning to direct their focus to the impact of technology. The result of this study showed that technology has clear benefits on the operational efficiency of the auditing process. Alongside these benefits, firms, however, need to overcome some of the challenges, some of which are not fully understood. There is no doubt that the disruptive technologies are having a profound impact on the skills required of auditors, and this has implications for educators and recruitment policies. The findings derived from the current study suggest that it is imperative for firms and educators to develop digital talents. It appears that IT and coding should be embedded into the educational syllabus because IT is no longer a niche subject area. Digital skills are the engine of the future's growth, hence there is a need for educational institutions to expose future graduates to such knowledge as it would help prepare them to practise auditing with more efficiency since digital technologies' utilisation offers many huge benefits. Auditing firms must not only focus on accounting technical skills when delivering or sending auditors for training. Instead, they need to blend the technical skills with digital skills so as to enhance the auditors' performance. Training institutions need to plan and design special training programmes which can increase the IT cognitive styles of auditors. Doing so would help to improve their attitude and their habitual strategies for recognising, remembering, thinking and problemsolving in their performance. With sufficient training and support from the top management, the auditors' competency could be improved, and digital technologies' utilisation could increase.

In response to the speed of technological and digital advances noted in the auditing context, it is imperative for audit firms and auditors to invest in these technologies, and to know how to use them. The parties involved may need to consider artificial intelligence, block chain, and other developments in data capabilities as a measure to ensure their competitiveness. It is important for audit firms to adopt digital technologies so that their audit strategies can be aligned with the clients' sophisticated accounting systems. The findings of this study also suggest 
that professional accounting bodies need to tighten the requirements in using digital technologies, and to provide support so as to encourage audit firms to use the tools.

While this study provides contributions to both academia and practice, it is also restricted by some limitations. First, the study only focused on external auditors, and not internal auditors in Jordan. Future studies may consider the internal auditors and their relationship with external auditors, whether in Jordan or other countries, so as to provide new insights into the audit profession. Second, this study had not considered the responses of stakeholders on the importance of IT and its relationship with external auditors. Future studies could focus on this area so as to uncover the IT gap between stakeholders and external auditors. It may also be useful for future research to identify stakeholders' satisfaction with external auditors' tasks. Finally, this study had only focused on the context of Jordan without considering other developing or developed countries. Future studies could therefore focus on other countries so as to provide new insights which could be compared professionally and specifically with regards to auditors' performance.

\section{References}

Ahmi, A. \& Kent, S. (2013). The utilization of generalized audit software (GAS) by external auditors. Managerial Auditing Journal, 28(2), 88-113. https://doi. org/10.1108/02686901311284522

Al-Ansi, A.A., Ismail, N.A., \& Al-Swidi, A.K. (2013). The effect of IT knowledge and IT training on the IT utilization among external auditors: Evidence from Yemen. Asian Social Science, 9(10), 307-323. https://doi.org/10.5539/ ass.v9n10p307

Al-Ansi, A.A.M. (2015). IT fit on auditors' performance in Yemen (Doctoral thesis, Universiti Utara Malaysia). https:/ / etd.uum.edu.my/5727/2/s93095_02.pdf

Al-Hanini, E. (2009). The role of using information technology in enhancing the quality of auditing services in Jordan - Empirical study at auditing offices and companies working in Jordan. An-Najah University Journal for Research (Humanities). https://repository.najah.edu/handle/20.500.11888/2801

Al-Kharbi, A.A.A. (2010). A study of the impact of 'IT' on audit and the role of auditing organizations to cope with the changing environment of the accounting systems with special reference to Republic of Yemen (Doctoral thesis, Bharati Vidyapeeth Deemed University, India).

American Institute of Certified Public Accountants (AICPA). (2011). Top technologies initiatives. https://www.aicpa.org/InterestAreas/Information Technology/Resources/TopTechnologyInitiatives/DownloadableDocum ents/2012-TTI-\%20whitepaper.pdf 
American Institute of Certified Public Accountants. (2012). Statements on quality control standards (SQCSs) 8: A firm's system of qualiy control, Section 10. https://www.aicpa.org/research/standards/auditattest/sqcs.html

Awa, H.O., Ojiabo, O.U., \& Emecheta, B.C. (2015). Integrating TAM, TPB and TOE frameworks and expanding their characteristic constructs for e-commerce adoption by SMEs. Journal of Science $\mathcal{E}$ Technology Policy Management, 6(1), 76-94. https://doi.org/10.1108/JSTPM-04-2014-0012

Bandura, A. (1997). Self-efficacy: The exercise of control. W.H. Freeman/Times Books/Henry Holt \& Co.

Berberich, G. (2005). The effects of audit methodology and audit experience on the development of auditors' knowledge of the clients' business. http://hdl.handle. net/10012/740

Bierstaker, J., Janvrin, D., \& Lowe, D.J. (2014). What factors influence auditors' use of computer-assisted audit techniques? Advances in Accounting, 30(1), 67-74. https:/ / doi.org/10.1016/j.adiac.2013.12.005

Braun, R.L., \& Davis, H.E. (2003). Computer-assisted audit tools and techniques: Analysis and perspectives. Managerial Auditing Journal, 18(9), 725-731. https://doi.org/10.1108/02686900310500488

Central Bank of Jordan. (2018). Financial stability report. http: / / www.cbj .gov.jo/ arabic/

Chakraborty, I., Hu, P.J-H., \& Cui, D. (2008). Examining the effects of cognitive style in individuals' technology use decision making. Decision Support Systems, 45(2), 228-241. https://doi.org/10.1016/j.dss.2007.02.003

Chwelos, P., Benbasat, I., \& Dexter, A.S. (2001). Research report: Empirical test of an EDI adoption model. Information Systems Research, 12(3), 304-321. https://doi.org/10.1287/isre.12.3.304.9708

Cristea, L.M. (2020). Emerging IT technologies for accounting and auditing practice. Audit Financiar, 18(4), 731-751. https://doi.org/10.20869/auditf/ 2020/160/023

Curtis, M.B., \& Payne, E.A. (2014). Modeling voluntary CAAT utilization decisions in auditing. Managerial Auditing Journal, 29(4), 304-326. https:// doi.org/10.1108/MAJ-07-2013-0903

Dbouk, B., \& Zaarour, I. (2017). Towards a machine learning approach for earnings manipulation detection. Asian Journal of Business $\mathcal{E}$ Accounting, 10(2), 215-251. https:/ / ajba.um.edu.my/article/view/9772

Gerrard, P., \& Cunningham, J.B. (2003). The diffusion of Internet banking among Singapore consumers. International Journal of Bank Marketing, 21(1), 16-28. https:// doi.org/10.1108/02652320310457776

Gibran, M. (2010, April 14-15). Factors affecting the quality of the audit from the viewpoint of Chartered Accountants in Yemen. Paper presented at the Conference on ways to develop the accounting profession in the Kingdom of Saudi Arabia, Jeddeh, Kingdom of Saudi Arabia.

Hair, J., Hollingsworth, C.L., Randolph, A.B., \& Chong, A.Y.L. (2017). An updated and expanded assessment of PLS-SEM in information systems 
research. Industrial Management \& Data Systems, 117(3), 442-458. https:// doi.org/10.1108/IMDS-04-2016-0130

Handoko, B.L., Ariyanto, S., \& Warganegara, D.L. (2018, July). Perception of financial auditor on usage of computer assisted audit techniques. Paper presented at the 3rd International Conference on Computational Intelligence and Applications (ICCIA). https:// doi.org/10.1109/ICCIA.2018.00052

Igbaria, M., Zinatelli, N., Cragg, P., \& Cavaye, A. (1997). Personal computing acceptance factors in small firms: A structural equation model. MIS Quarterly, 1(3), 279-302. https://doi.org/10.2307/249498

International Accounting Education Standards Board. (2014). Initial professional development - professional skills ( Revised ). https://www.iaesb.org/

International Federation of Accountants (2019). Handbook of international education pronouncements. International Federation of Accountants. https://www. iaesb.org/publications/2019-handbook-international-education-standards

Iskandar, T.M., Sari, R.N., Mohd-Sanusi, Z., \& Anugerah, R. (2012). Enhancing auditors' performance: The importance of motivational factors and the mediation effect of effort. Managerial Auditing Journal, 27(5), 462-476. https:// doi.org/10.1108/02686901211227959

Ismail, N.A., \& Abidin, A.Z. (2009). Perception towards the importance and knowledge of information technology among auditors in Malaysia. Journal of Accounting and Taxation, 1(4), 61-69. https:// doi.org/10.5897/JAT09.017

Issa, H., Sun, T., \& Vasarhelyi, M.A. (2016). Research ideas for artificial intelligence in auditing: The formalization of audit and workforce supplementation. Journal of Emerging Technologies in Accounting, 13(2), 1-20. https://doi.org/10.2308/jeta-10511

Jordanian Association of Certified Public Accountants (2019). Jordanian certified public accountant 2019. https://jacpa.org.jo/ar-jo/home.aspx

Kozlowski, S. (2018). An audit ecosystem to support blockchain-based accounting and assurance. In D.Y. Chan, V. Chiu, \& M.A. Vasarhelyi (Eds.), Continuous Auditing (pp. 299-313). Emerald Publishing Limited. https:// doi.org/10.1108/978-1-78743-413-420181015

La Torre, M., Botes, V.L., Dumay, J., Rea, M.A., \& Odendaal, E. (2018). The fall and rise of intellectual capital accounting: New prospects from the Big Data revolution. Meditari Accountancy Research, 26(3), 381-399. https://doi. org/10.1108/MEDAR-05-2018-0344

Lamboglia, R., \& D'Onza, G. (2014). IT auditing in Italian banks: An explanatory study. In D. Baglieri, C. Metallo, C. Rossignoli, M. Pezzillo Iacono (Eds.), Information systems, management, organization and control (pp. 99-114). Springer Cham. https://doi.org/10.1007/978-3-319-07905-9_7

Lee, C.S., \& Tajudeen, F.P. (2020). Impact of artificial intelligence on accounting: Evidence from Malaysian organisations. Asian Journal of Business and Accounting, 13(1), 213-239. https://doi.org/10.22452/ajba.vol13no1.8

Lim-u-sanno, K., \& Ussahawanitchakit, P. (2009). Audit risk judgment and performance of Thai auditors: An empirical investigation of their 
antecedents and consequences. Journal of Academy of Business and Economics, 9(3), 59-83.

Lin, H-F. \& Lin, S-M. (2008). Determinants of e-business diffusion: A test of the technology diffusion perspective. Technovation, 28(3) 135-145. https://doi. org/10.1016/j.technovation.2007.10.003

Lois, P., Drogalas, G., Karagiorgos, A., \& Tsikalakis, K. (2020). Internal audits in the digital era: Opportunities risks and challenges. EuroMed Journal of Business, 15(2), 205-217. https:/ / doi.org/10.1108/emjb-07-2019-0097

Mansour, E.M. (2016). Factors affecting the adoption of computer assisted audit techniques in audit process: Findings from Jordan. Business and Economic Research, 6(1), 248-271. https://doi.org/10.5296/ber.v6i1.8996

Marie, A. (2015). The electronic audit and its impact on the audit quality at audit firms in Jordan (Field Study) (Master's Thesis, Zarqa University, Jordan).

Messick, S. (1976). Personality consistencies in cognition and creativity. In S. Messick and Associates (Ed.), Individuality in learning (pp. 4-22). JosseyBass.

Oliveira, T., \& Martins, M.F. (2008, July). A comparison of web site adoption in small and large Portuguese firms. In F. Joaquim, D.A. Marca, S. Boris, \& M. van Sinderen (Eds.), Proceedings of the International Conference on e-Business (pp. 370-377). IEEE.

Pan, M.J., \& Jang, W.Y. (2008). Determinants of the adoption of enterprise resource planning within the technology-organization-environment framework: Taiwan's communications. Journal of Computer Information Systems, 48(3), 94-102. https://doi.org/10.1080/08874417.2008.11646025

Pratoomsuwan, T. (2017). Audit prices and Big 4 fee premiums: Further evidence from Thailand. Journal of Accounting in Emerging Economies, 7(1), 2-15. https:// doi.org/10.1108/jaee-07-2014-0039

Ragu-Nathan, B.S., Apigian, C.H., Ragu-Nathan, T.S., \& Tu, Q. (2004). A path analytic study of the effect of top management support for information systems performance. Omega, 32(6), 459-471. https://doi.org/10.1016/j. omega.2004.03.001

Schwarzer, R. (2014). Self-efficacy: Thought control of action. Taylor \& Francis. https://doi.org/10.4324/9781315800820

Serpeninova, Y., Makarenko, S., \& Litvinova, M. (2020). Computer-assisted audit techniques: Classification and implementation by auditor. Public Policy and Accounting, 1(1), 44-49. https://doi.org/10.26642/ppa-2020-1-44-49

Sikka, P. (2009). Financial crisis and the silence of the auditors. Accounting, Organisations and Society, 34(6-7), 868-873. https://doi.org/10.1016/j. aos.2009.01.004

Takeuchi, T., Wada, T., Mukobaru, M., \& Doi, S. (2007, May). A training system for myoelectric prosthetic hand in virtual environment. In 2007 IEEE/ICME International Conference on Complex Medical Engineering (pp. 1351-1356). IEEE. https:// doi.org/10.1109/ICCME.2007.4381964 
Tornatzky, L.G., \& Fleischer, M. (1990). The processes of technological innovation. Lexington Books.

Venkatesh, V., Morris, M.G., Davis, G.B., \& Davis, F.D. (2003). User acceptance of information technology: Toward a unified view. MIS Quarterly, 27(3), 425-478. https://doi.org/10.2307/30036540

Wicaksono, A., \& Lusianah, L. (2016). Impact analysis of generalized audit software (GAS) utilization to auditor performances. Binus Business Review, 7(2), 131-136. https:// doi.org/10.21512/bbr.v7i2.1582

Yi, M.Y., \& Davis, F.D. (2001). Improving computer training effectiveness for decision technologies: Behavior modeling and retention enhancement. Decision Sciences, 32(3), 521-544. https://doi.org/10.1111/j.1540-5915.2001. tb00970.x

\section{Appendix 1}

Measurement of Variables

\begin{tabular}{|c|c|c|c|}
\hline Variables & Items & Questions & Sources \\
\hline IT knowledge & $\begin{array}{l}\text { ITK1 } \\
\text { ITK2 } \\
\text { ITK3 } \\
\text { ITK4 } \\
\text { ITK5 }\end{array}$ & $\begin{array}{l}\text { I have good knowledge of general } \\
\text { office automation. } \\
\text { I have good knowledge of } \\
\text { accounting firm office automation. } \\
\text { I have good knowledge of audit } \\
\text { automation. } \\
\text { I have good knowledge of } \\
\text { e-commerce technologies. } \\
\text { I have good knowledge of system } \\
\text { design and implementation. }\end{array}$ & $\begin{array}{l}\text { Ismail \& } \\
\text { Abidin (2009) }\end{array}$ \\
\hline $\begin{array}{l}\text { IT Cognitive } \\
\text { Style }\end{array}$ & $\begin{array}{l}\text { ITCS1 } \\
\text { ITCS2 } \\
\text { ITCS3 } \\
\text { ITCS4 } \\
\text { ITCS5 }\end{array}$ & $\begin{array}{l}\text { I usually have original ideas. } \\
\text { I like to proliferate (increase) ideas. } \\
\text { I am self-motivated person. } \\
\text { I usually think critical to show my } \\
\text { work problems. } \\
\text { I like to cope with several new } \\
\text { ideas at the same time. }\end{array}$ & $\begin{array}{c}\text { Chakraborty et } \\
\text { al. (2008) }\end{array}$ \\
\hline IT Self-Efficacy & $\begin{array}{l}\text { ITSE1 } \\
\text { ITSE2 }\end{array}$ & $\begin{array}{l}\text { I am capable to achieve the goals } \\
\text { I have set for myself. } \\
\text { I have the IT skills that help me to } \\
\text { accomplish my tasks. }\end{array}$ & $\begin{array}{l}\text { Iskandar et al. } \\
\text { (2012) }\end{array}$ \\
\hline
\end{tabular}




\section{Appendix 1 (continued)}

Measurement of Variables

\begin{tabular}{|c|c|c|c|}
\hline Variables & Items & Questions & Sources \\
\hline & $\begin{array}{l}\text { ITSE4 } \\
\text { ITSE5 } \\
\text { ITSE6 }\end{array}$ & $\begin{array}{l}\text { In general, I think that I can utilise } \\
\text { the IT to obtain outcomes that are } \\
\text { important to me. } \\
\text { I be able to successfully use IT to } \\
\text { overcome many challenges. } \\
\text { I am confident that I have IT } \\
\text { knowledge to help me to role } \\
\text { effectively on many different tasks. } \\
\text { I have IT skills that enable me to } \\
\text { do most tasks very well. }\end{array}$ & \\
\hline $\begin{array}{l}\text { Management } \\
\text { Support }\end{array}$ & $\begin{array}{l}\text { ITMS1 } \\
\text { ITMS2 } \\
\text { ITMS3 } \\
\text { ITMS4 }\end{array}$ & $\begin{array}{l}\text { Top management is interested in } \\
\text { IT function. } \\
\text { Top management in my firm is } \\
\text { aware of the benefits that can be } \\
\text { achieved by using audit technology. } \\
\text { Top management always supports } \\
\text { and encourages the use of audit } \\
\text { technology. } \\
\text { Top management keeps the } \\
\text { pressure on auditors to use IT. }\end{array}$ & $\begin{array}{l}\text { Ragu-Nathan } \\
\text { et al. (2004) }\end{array}$ \\
\hline IT Training & $\begin{array}{l}\text { ITT3 } \\
\text { ITT4 }\end{array}$ & $\begin{array}{l}\text { Continuous IT training provided by } \\
\text { firm helps me to do my auditing job } \\
\text { more efficiently. } \\
\text { Comprehensive IT training } \\
\text { programs provided by firm are } \\
\text { important in enhancing my } \\
\text { auditing job. } \\
\text { Training programs provided by } \\
\text { firm developed my IT skills and } \\
\text { knowledge. } \\
\text { IT Training programs provided by } \\
\text { firm enhanced my auditing job } \\
\text { experiences. }\end{array}$ & $\begin{array}{l}\text { Takeuchi et al. } \\
\text { (2007) }\end{array}$ \\
\hline $\begin{array}{l}\text { IT Facilitating } \\
\text { Resources }\end{array}$ & ITFR1 & $\begin{array}{l}\text { I have the resources necessary to } \\
\text { use the information techniques } \\
\text { used in this organisation. }\end{array}$ & $\begin{array}{l}\text { Curtis \& } \\
\text { Payne (2014) }\end{array}$ \\
\hline
\end{tabular}




\section{Appendix 1 (continued)}

Measurement of Variables

\begin{tabular}{|c|c|c|c|}
\hline Variables & Items & Questions & Sources \\
\hline & ITFR2 & $\begin{array}{l}\text { Information techniques used in this } \\
\text { organisation are compatible with } \\
\text { other audit software I use. } \\
\text { Assistance is available for system } \\
\text { difficulties when I use the } \\
\text { information techniques used in this } \\
\text { organisation. }\end{array}$ & \\
\hline & ITFR4 & $\begin{array}{l}\text { Specialised instructions concerning } \\
\text { the information techniques are } \\
\text { available to me. }\end{array}$ & \\
\hline & ITFR5 & $\begin{array}{l}\text { Information techniques used in this } \\
\text { organisation fits well with the } \\
\text { firm's audit approach. }\end{array}$ & \\
\hline \multirow{3}{*}{$\begin{array}{l}\text { Complexity of } \\
\text { Clients' IT } \\
\text { System }\end{array}$} & CCS1 & $\begin{array}{l}\text { Auditing in a highly automated } \\
\text { system is complex. }\end{array}$ & \multirow{3}{*}{$\begin{array}{l}\text { Gerrard \& } \\
\text { Cunningham } \\
(2003)\end{array}$} \\
\hline & CCS2 & $\begin{array}{l}\text { Auditing clients use complex IT } \\
\text { systems involving complex } \\
\text { procedures. }\end{array}$ & \\
\hline & CCS3 & $\begin{array}{l}\text { Computer-related audit procedures } \\
\text { are difficult to understand. }\end{array}$ & \\
\hline \multirow[t]{4}{*}{$\begin{array}{l}\text { Competitive } \\
\text { Pressure }\end{array}$} & CP1 & $\begin{array}{l}\text { As a response to the competition, } \\
\text { I use IT to perform my audit job. }\end{array}$ & \multirow[t]{4}{*}{$\begin{array}{l}\text { Chwelos et al } \\
(2001)\end{array}$} \\
\hline & $\mathrm{CP} 2$ & $\begin{array}{l}\text { In the audit firms, the adoption of } \\
\text { IT is helpful in allowing an } \\
\text { organisation to remain competitive. }\end{array}$ & \\
\hline & CP3 & $\begin{array}{l}\text { There is pressure to adopt IT } \\
\text { placed on my audit firm by our } \\
\text { competitors. }\end{array}$ & \\
\hline & $\mathrm{CP} 4$ & $\begin{array}{l}\text { It is important to apply the latest } \\
\text { technology to stay competitive. }\end{array}$ & \\
\hline \multirow{2}{*}{$\begin{array}{l}\text { Regulation of } \\
\text { Professional } \\
\text { Bodies in } \\
\text { Jordan }\end{array}$} & RPBJ1 & $\begin{array}{l}\text { Regulation of Professional Bodies } \\
\text { takes into consideration the } \\
\text { continuous development of IT. }\end{array}$ & \multirow[t]{2}{*}{$\begin{array}{l}\text { Al-Kharbi } \\
(2010)\end{array}$} \\
\hline & RPBJ2 & $\begin{array}{l}\text { Regulation of Professional Bodies } \\
\text { takes into consideration the audit } \\
\text { procedures in IT. }\end{array}$ & \\
\hline
\end{tabular}




\section{Appendix 1 (continued)}

Measurement of Variables

\begin{tabular}{|c|c|c|c|}
\hline \multirow[t]{5}{*}{ Variables } & Items & Questions & Sources \\
\hline & RPBJ3 & $\begin{array}{l}\text { Professional bodies such as JACPA } \\
\text { provide the essential framework of } \\
\text { the audit procedures in the } \\
\text { computerised environment. }\end{array}$ & \\
\hline & RPBJ4 & $\begin{array}{l}\text { Professional bodies such as JACPA } \\
\text { work to promote the profession of } \\
\text { audit to cope with IT. }\end{array}$ & \\
\hline & RPBJ5 & $\begin{array}{l}\text { Professional bodies have ability to } \\
\text { change the auditing competitive } \\
\text { environment. }\end{array}$ & \\
\hline & RPBJ6 & $\begin{array}{l}\text { There is a relationship between the } \\
\text { professional bodies such as JACPA } \\
\text { and the international professional } \\
\text { organisations to develop the audit. }\end{array}$ & \\
\hline \multirow[t]{4}{*}{$\begin{array}{l}\text { Auditors' } \\
\text { Performance }\end{array}$} & AP1 & $\begin{array}{l}\text { I found the information techniques } \\
\text { used in this organisation useful in } \\
\text { my electronic audit job. }\end{array}$ & $\begin{array}{l}\text { Curtis \& } \\
\text { Payne (2014) }\end{array}$ \\
\hline & AP2 & $\begin{array}{l}\text { I found using the information } \\
\text { techniques used in this organisation } \\
\text { enabled me to accomplish tasks } \\
\text { more quickly. }\end{array}$ & \\
\hline & AP3 & $\begin{array}{l}\text { I found using the information } \\
\text { techniques used in this organisation } \\
\text { increased my overall productivity. }\end{array}$ & \\
\hline & $\mathrm{AP} 4$ & $\begin{array}{l}\text { I found using the information } \\
\text { techniques used in this organisation } \\
\text { increased my chances of getting a } \\
\text { raise. }\end{array}$ & \\
\hline \multirow{7}{*}{$\begin{array}{l}\text { Digital } \\
\text { Technologies' } \\
\text { Utilisation }\end{array}$} & DTU1 & Utilisation of General Office & \multirow{7}{*}{$\begin{array}{l}\text { Ismail \& } \\
\text { Abidin (2009) }\end{array}$} \\
\hline & & Automation. & \\
\hline & DTU2 & $\begin{array}{l}\text { Utilisation of Accounting Firm } \\
\text { Office Automation. }\end{array}$ & \\
\hline & DTU3 & Utilisation of Audit Automation. & \\
\hline & DTU4 & Utilisation of E-Commerce & \\
\hline & & Technologies. & \\
\hline & DTU5 & $\begin{array}{l}\text { Utilisation of System Design and } \\
\text { Implementation. }\end{array}$ & \\
\hline
\end{tabular}


